\title{
KETERAMPILAN MENULIS TEKS BERITA MENGGUNAKAN TEKNIK MENGAMATI, MENIRU, DAN MENAMBAHI (3M)
}

\author{
Firmansyah, H. M. Amin Menne, dan H. Tajuddin Posi \\ ${ }^{1,2,3}$ Universitas Muhammadiyah Sidenreng Rappang \\ Jl. Angkatan 45 No 1A Lautang Salo Rappang, Pancarijang, Sidenreng Rappang \\ firmansyah22@gmail.com
}

\begin{abstract}
Abstrak: Keterampilan Menulis Teks Berita Menggunakan Teknik Mengamati, Meniru, dan Menambah (3M). Tujuan penelitian ini adalah mendeskripsikan peningkatan keterampilan menulis teks berita selama mengikuti pembelajaran dengan teknik $3 \mathrm{M}$. Penelitian ini merupakan penelitian tindakan kelas yang terdiri prasiklus, siklus I, dan siklus II. Data dikumpulkan dengan cara tes menulis berita. Data dianalisis dengan menggunakan statistik deskriktif dalam bentuk nilai rata-rata. Berdasarkan hasil analisis data diketahui bahwa nilai rata-rata siswa pada tahap prasiklus yaitu 62,37 , pada siklus I sebesar 73,68, dan pada siklus II menjadi 79,31. Hal ini menunjukkan adanya peningkatan nilai rata-rata dari tahap prasiklus hingga siklus II sebesar 20,40\%. Oleh karena itu, dapat disimpulkan bahwa keterampilan menulis teks berita siswa meningkat dengan menggunakan teknik 3M.
\end{abstract}

Kata kunci: menulis, teknik 3M, teks berita

\begin{abstract}
News Text Writing Skills Using Observing, Copying and Adding (3M) Techniques. The purpose of this study is to describe the improvement of news text writing skills while participating in learning with $3 \mathrm{M}$ techniques. This research is a class action research consisting of pre-cycle, cycle I, and cycle II. Data was collected by means of a news writing test. Data were analyzed using descriptive statistics namely mean. Based on the results of data analysis it is known that the average value of students in the pre-cycle stage is 62,37 , in the first cycle of 73,68 , and in the second cycle to 79,31 . This shows an increase in the average value from the pre-cycle stage to the second cycle of $20,40 \%$. Therefore, it can be concluded that the writing skills of students' news texts improve by using the $3 \mathrm{M}$ technique.
\end{abstract}

Keywords: news text, writing, 3M technique

Keterampilan menulis sebagai keterampilan berbahasa bersifat produktif aktif merupakan salah satu kompetensi dasar berbahasa yang harus dimiliki siswa agar terampil mengorganisasikan gagasan dengan runtut, menggunakan kosakata yang tepat dan sesuai, memperhatikan ejaan dan tanda baca yang benar, serta menggunakan ragam kalimat yang efektif dan variatif dalam menulis jika memiliki kompetensi menulis yang baik.

Dalam kaitannya dengan pembelajaran menulis pada tingkat SMP menulis teks berita merupakan salah satu kompetensi yang diharapkan bisa memberikan gambaran kepada siswa tentang dunia tulis-menulis.

Keterampilan menulis teks berita di kelas terkadang juga hanya diajarkan pada saat pembelajaran menulis saja, padahal pembelajaran keterampilan menulis teks berita dapat diintegrasikan dalam setiap proses pembelajaran di kelas. Baik secara internal maupun eksternal. Pengintegrasian internal berarti pembelajaran menulis teks berita diintegrasikan dalam pembelajaran keterampilan berbahasa yang lain seperti menyimak, membaca, dan berbicara. Menulis teks berita dapat pula diintegrasikan secara 
eksternal dengan mata pembelajaran lain di luar mata pembelajaran Bahasa Indonesia.

Oleh karena itu, diperlukan suatu teknik pembelajaran yang tepat untuk meningkatkan keterampilan menulis teks berita. Teknik ini bukan bukan untuk mengkombinasikan suasana pembelajaran, melainkan suatu kiat, siasat, atau penemuan yang digunakan untuk menyeleikan serta menyempurnakan suatu tujuan langsung (Kuwat 2008).

Penulisan berkeyakinan bahwa penggunaan teknik $3 \mathrm{M}$ dapat mempermudah siswa untuk menguasai kompetensi menulis teks berita. Kuwat (2008) menyebutkan teknik 3M merupakan kependekan dari mengamati, meniru dan menambahi. Teknik 3M tidak sulit diterapkan dalam pembelajaran menulis teks berita baik untuk SMP di perkotaan maupun di pedesaan. Kemauan gurulah kuncinya. Teknik 3M juga sangat mungkin diterapkan pada pembelajaran keterampilan menulis yang lain, seperti menulis cerpen, pengumuman, iklan baris, dan surat.

\section{METODE}

Pelaksanaan penelitian ini menggunakan desain penelitian tindakan kelas (PTK) yang dilakukan pada VIII SMP Negeri 3 Baranti Kabupaten Sidenreng Rappang. Penelitian ini terdiri dari tahap prasiklus, siklus I, dan siklus II. Prasiklus dilakukan untuk mengetahui kondisi siswa dalam kelas, kesulitan yang dialami siswa, dan sebagai bahan refleksi untuk perencanaan pembelajaran siklus I. Kemudian, hasil pembelajaran siklus I digunakan sebagai acuan perencanaan pembelajaran siklus II. Hasil pembelajaran siklus II digunakan untuk mengetahui peningkatan hasil belajar dari tahap prasiklus sampai dengan siklus II. Tiap siklus terdiri dari empat komponen yaitu perencanaan, tindakan observasi, dan refleksi.

\section{HASIL DAN PEMBAHASAN}

Hasil penelitian yang disajikan berupa hasil menulis teks berita pada tahap prasiklus, siklus I, dan siklus II.
Tabel 1 Hasil Tes Menulis Teks Berita Prasiklus

\begin{tabular}{cccccc}
\hline Kategori & $\begin{array}{c}\text { Rentang } \\
\text { Nilai }\end{array}$ & $\mathrm{f}$ & $\mathrm{x}$ & $\mathrm{fx}$ & $\%$ \\
\hline $\begin{array}{c}\text { Sangat } \\
\text { baik }\end{array}$ & $\geq 85$ & 0 & 92,5 & 0 & 0 \\
\hline Baik & $70-84$ & 9 & 77 & 693 & 19,15 \\
\hline Cukup & $60-69$ & 29 & 64 & 1856 & 61,70 \\
\hline Kurang & $<60$ & 9 & 42,5 & 382,5 & 19,15 \\
\hline \multicolumn{2}{c}{ Jumlah } & 47 & 276 & $\begin{array}{c}2931, \\
5\end{array}$ & 100 \\
\hline Nilai rata-rata & $2931,5 / 47 \times 100=62,37$ \\
\hline
\end{tabular}

Data tabel 1 menunjukkan nilai ratarata siswa pada tes prasiklus sebesar 62,37. Nilai itu termasuk dalam kategori cukup.

Hasil tes siklus I adalah keterampilan siswa dalam menulis teks berita dengan menggunkan teknik 3M. Media atau model yang digunakan adalah tiga teks berita dari koran yang bertemakan banjir soal tes yang digunakan adalah gambar tentang musibah banjir. Hasil menulis berita dengan menggunakan teknik $3 \mathrm{M}$ dapat diihat pada tabel berikut ini.

Tabel 2 Data Hasil Tes Menulis Teks Berita Siklus I

\begin{tabular}{cccccc}
\hline Kategori & $\begin{array}{c}\text { Rentang } \\
\text { nilai }\end{array}$ & $\mathrm{f}$ & $\mathrm{x}$ & $\mathrm{fx}$ & $\%$ \\
\hline $\begin{array}{c}\text { Sangat } \\
\text { baik }\end{array}$ & $\geq 85$ & 0 & 92,5 & 0 & 0 \\
\hline Baik & $70-84$ & 35 & 77 & 2695 & 74,47 \\
\hline Cukup & $60-69$ & 12 & 64 & 768 & 25,53 \\
\hline Kurang & $\leq 60$ & 0 & 42,5 & 0 & 0 \\
\hline \multicolumn{2}{c}{ Jumlah } & 47 & & 3463 & 100 \\
\hline
\end{tabular}

Nilai rata-rata $3463 / 47=73,68$

Berdasarkan data pada tabel 2 dapat diketahui nilai rata-rata menulis teks berita pada siklus I mencapai 73,68 dan termasuk dalam kategori baik. Di antara 47 siswa tidak ada siswa yang memperoleh nilai dalam kategori sangat baik dan kurang. Frekuensi terbanyak adalah siswa yang memperoleh nilai dalam kategori baik sejumlah 35 siswa atau $74,47 \%$. Kemudian, 12 siswa sisanya atau $25,53 \%$ adalah siswa yang memperoleh nilai dalam kategori cukup.

Hasil tes siklus II adalah keterampilan siswa dalam menulis teks berita dengan menggunakan teknik 3M. Media atau model yang digunakan sama dengan media pada siklus I yaitu tiga teks berita dari koran yang bertemakan banjir. Soal tes yang digunakan adalah gambar tentang musibah banjir yang melanda SMK Nusantara. Hasil menulis 
berita dengan meggunakan teknik 3M dapat dilihat pada tabel berikut ini.

Tabel 3 Hasil Tes Menulis Teks Berita Siklus II

\begin{tabular}{cccccc}
\hline Kategori & $\begin{array}{c}\text { Rentang } \\
\text { Nilai }\end{array}$ & $\mathrm{f}$ & $\mathrm{x}$ & $\mathrm{fx}$ & $\%$ \\
\hline $\begin{array}{c}\text { Sangat } \\
\text { baik }\end{array}$ & $\geq 85$ & 7 & 92,5 & 647,5 & 14,90 \\
\hline Baik & $70-84$ & 40 & 77 & 3080 & 85,10 \\
\hline Cukup & $60-69$ & 0 & 64 & 0 & 0 \\
\hline Kurang & $<60$ & 0 & 42,5 & 0 & 0 \\
\hline \multicolumn{3}{c}{ Jumlah } & 47 & & 3727, \\
5 & 100 \\
\hline \multicolumn{5}{c}{ Nilai rata-rata $=3727,5 / 47=79,31$}
\end{tabular}

Berdasarkan data pada tabel 3 dapat diketahui bahwa nilai rata-rata menulis teks berita pada siklus II mencapai 79,31 dan termasuk dalam kategori baik. Ada 7 siswa yang memperoleh nilai dalam kategori sangat baik atau sebesar 14,90\%. Frekuensi terbanyak adalah siswa yang memperoleh nilai dalam kategori baik yang mencapai 40 siswa atau $80,10 \%$. Dalam siklus II tidak ada siswa yang memperoleh nilai dalam kategori cukup dan kurang.

\section{PEMBAHASAN}

Berdasarkan data hasil pembahasan yang dilakukan pada tahap prasiklus, siklus I, dan suklus II, dapat diketahui bahwa terjadi peningkatan hasil belajar siswa kelas VIII SMP Negeri 3 Baranti Tahun Ajaran

\section{DAFTAR PUSTAKA}

Kuwat. 2008. Pembelajaran Menulis Teks Berita dengan Teknik 3M. Online. http://pembelajarandismp.wordpress.com/ 2008/05/24/pembelajaran-menulis-teksberita-dengan-teknik-3m, diakses tanggal 12 Maret 2019.
2018/2019. Pembelajaran prasiklus menggunakan metode pembelajaran konversional atau ceramah, sedangkan pembelajaran siklus I dan II menggunakan teknik 3M. Peningkatan hasil belajar siswa juga diikuti dengan perubahan perilaku siswa ke arah yang positif.

Nilai rata-rata pada tahap prasiklus sebesar 62,37. Nilai rata-rata siklus I adalah 73,68 , sedangkan nilai rata-rata siklus II mencapai 79,31. Dengan demikian, dapat disimpulkan bahwa disimpulkan bahwa peningkatan hasil menulis teks berita dari tahap prasiklus ke siklus I adalah $18,31 \%$. Peningkatan hasil tes menulis teks berita dari siklus I ke siklus II adalah 7,64\%. Jadi, peningkatan hasil tes menulis teks berita prasiklus sampai siklus II adalah 27,16\%.

\section{PENUTUP}

Keterampilan menulis teks berita siswa kelas VIII SMP Negeri 3 Baranti tahun ajaran 2018-2019 mengalami peningkatan setelah dilakukan pembelajaran menggunakan teknik 3M. Oleh karena itu, disarankan kepada guru Bahasa Indonesia untuk menjadikan teknik $3 \mathrm{M}$ sebagai salah satu teknik dalam pembelajaran menulis.

Subyantoro. 2007. Penelitian Tindakan Kelas. Semarang: Rumah Indonesia.

Sudjana. 2002. Statistika. Bandung: Tarsito 